\title{
Creativity: a key Durkheimian concern and problematic
}

William Watts Miller

\section{(2) OpenEdition}

1 Journals

\section{Electronic version}

URL: http://journals.openedition.org/ress/3887

DOI: $10.4000 /$ ress.3887

ISBN: $1663-4446$

ISSN: $1663-4446$

Publisher

Librairie Droz

Printed version

Date of publication: 15 December 2017

Number of pages: 17-40

ISSN: 0048-8046

\section{Electronic reference}

William Watts Miller, "Creativity: a key Durkheimian concern and problematic", Revue européenne des sciences sociales [Online], 55-2 | 2017, Online since 15 December 2020, connection on 19 January 2021. URL: http://journals.openedition.org/ress/3887 ; DOI: https://doi.org/10.4000/ress.3887 


\title{
CREATIVITY: \\ A KEY DURKHEIMIAN CONCERN AND PROBLEMATIC
}

\author{
WILLIAM WATTS MILLER \\ University of Oxford, British Centre for Durkheimian Studies \\ wwattsmiller@gmail.com
}

\begin{abstract}
This article mainly employs a traditional approach of textual analysis to open up a relatively neglected topic, the question of creativity in Durkheim's work, but especially in Les Formes élémentaires de la vie religieuse. It is also especially in a focus on his insistence on a sui generis social realm, while in the course of this exploring his use of terms such as "substratum", "fusion", and "synthesis", as well as examining issues of duality, effervescence, rhythms of life and revolutions. It concludes with his worries over a modern crisis and with his hope in the creative energies of effervescence to try to overcome it.
\end{abstract}

Keywords: creativity, duality, effervescence, Émile Durkheim, Formes élémentaires, rhythms and revolutions, sui generis social realm.

Résumé. Cet article s'appuie sur la méthode traditionnelle de l'analyse textuelle pour venir à bout d'un sujet relativement négligé, à savoir la question de la créativité dans l'œuvre d'Émile Durkheim, et en premier lieu dans Les Formes élémentaires de la vie religieuse. L'article s'arrête notamment sur l'idée de Durkheim selon laquelle la société serait une réalité sui generis, explore l'usage qu'il fait de termes tels que «substrat», «fusion» et «synthèse», et examine les problèmes liés à certaines notions auxquelles il a recours, comme celles de dualité, effervescence, rythmes et bouleversements de la vie collective. L'article conclut sur les inquiétudes de Durkheim quant à une crise de la modernité et les espoirs qu'il place dans les énergies créatives de l'effervescence pour essayer de la surmonter.

Mots-clés: créativité, dualité, effervescence, Émile Durkheim, Formes élémentaires, rythme et révolution, spécificité des phénomènes sociaux. 
Modern scholarship on Émile Durkheim's work, life and times has blossomed in many ways, with new discoveries, new methods of research, new questions and new interests. But it still seems to me of value to pursue, as mainly done here, the rather more traditional approach of textual analysis, although I have taken advantage of the easy, indeed instant access to original editions thanks to modern digital technology, and although my concern is with opening up an issue that has perhaps been unduly neglected. Moreover, Durkheim himself never employed the term, créativité, which did not become current in French until the 1940s and 1950' ${ }^{\mathrm{I}}$.

\section{CREATIVITY IN LES FORMES}

The issue of creativity can be seen as a key concern and problematic built into Durkheim's sociology from the start. But a way to explore this is to begin with the approach to the issue in his last great work, Les Formes élémentaires de la vie religieuse (1912). The "creative", like the "dynamic", was one of the intellectual buzzwords of the I90os, and the work, with all its references to "creation", "creating" and "creative power", clearly involves some or other idea of creativity.

\section{I. CAUSALITY AND CREATIVITY: BOOK III}

There has been much interest among commentators on Les Formes in the discussion of causality and science that occurs at book III, chapter III, section III, p.518-528. But it is usually without noticing how it is followed, a mere ten pages later, with a discussion of creativity and art at book III, chapter IV, section II, p.537-548. If it is bad enough that this coverage of art has often been ignored, it is perhaps still worse that there has been hardly any attempt to surmount the gap of a few pages and link the work's sections on science and art to ask about a basic question at stake in them, which is Durkheim's view of the whole relation between causality and creativity. 
Given Durkheim's commitment to sociology as science, it is understandable that there has been such interest in his account of causality, as in the work, for example, of Warren Schmaus (1994; 2004) and Anne Rawls (2004). However, the relation between causality and creativity is raised in a critique of both these authors by Susan Stedman Jones (2006), who emphasizes Durkheim's concern with "the dynamic and creative nature of the categories that constellate around action-particularly causality, which involves the power to do" (ibid., p.64).

The slightly different strategy I wish to pursue here is to assume that Durkheim's ideas of causality and creativity cannot just be the same, however much they overlap, and to look for what might help to distinguish his notion of creativity by starting from the case of art.

\section{I.2. CREATIVITY IN ART}

Although, like the discussion of science, the one on art is also quite short, it might still seem remarkable that it says nothing about beauty. Art, for Durkheim, instead comes across as above all an affair of the exercise and enjoyment of a creative power. In a passage that talks of "imagination", "free creations of the mind" and "free combinations of thought and action", art is characterized in terms of the key idea of a "surplus", involving energies that sweep beyond the practically appropriate or necessary (Durkheim, I9I2, p.544-546).

It is essential, of course, to interpret things in context, and to notice how this account is part of a chapter on "representative or commemorative rites". These, it emerges, consist of more or less theatrical enactments of sacred myth, and so could also be discussed as sacred drama. As such, they mobilize and combine different particular varieties of art, especially varieties of performative and bodily art-music, dance, song, chant, verse, story-telling, special costumes, face-paintings and so on, but also and not least, the power of a whole atmospheric mise-en-scène. Indeed, Durkheim's star case of sacred drama comes, not from Baldwin Spencer and Francis James Gillen's pioneering Australian ethnography of I899, but from their follow-up study of 1904, and is a rite among the Warramunga people that they pick out as special. "It is not possible to convey in 
words anything like an adequate idea of this series of ceremonies, which were the most impressive of any that we witnessed" (Spencer and Gillen, 1904, p.247).

Moreover, it is also the rite that Durkheim had already used as his star case of collective creative effervescence, in an account located in the chapter that constitutes the physical as well as intellectual centrepiece of Les Formes, namely, book II, chapter VII. After describing the rite in some detail, he suggests it was the effervescence stirred up in such social milieux that gave birth to "the religious idea" (Durkheim, 1912, p.313). But his theorization of effervescence at this key, revelatory point of the work highlights a combination of the power of assembly and the power of symbolism, with little or nothing explicit on the role of art until around two hundred pages later. So it might be wondered if, just as some of his official, programmatic statements attempt to play down physical, material embodiment, there is also an effort to marginalize art. Certainly, art is a pervasive, implicit presence in the centrepiece's description of effervescence in Australia, if only thanks to Durkheim's reliance on Spencer and Gillen. Not only do they conclude their ethnographies of I899 and 1904 with long accounts of the art of the Australian peoples, but they also weave aesthetics into their ongoing, detailed ethnography itself, as, for example, in their interest in the powerful, striking art of the Arunta people's churingas or of the Warramunga people's ground-drawings, both of which had a central role in ritual. Yet on the one hand, Durkheim was quite capable of misrepresenting the available ethnography, as in his emphasis solely on a "mimetic" imitation of totems, contrary to all the evidence of cases such as the churingas and ground-drawings. On the other hand, when he finally gets round to the issue of art, he insists, for example, on "a poetry inherent in all religion" (ibid., p.546), and in this and other ways it becomes apparent from his work's overall argument about collective creative effervescence that it fuses the power of assembly, the power of symbolism and the power of art.

But the upshot is not just that art, complete with its imaginativeness, free combinations of thought and action and energies of a surplus, is an integral element of the dynamics that help to give birth to "the religious idea". As part of these effervescent processes, art is also part of the same dynamics that help to create and constitute social life itself. 


\section{I.3. CREATIVITY IN GENERAL}

Book I of Les Formes sets out to clear the ground for Durkheim's own approach to religion by eliminating the two main rival theories, and a fundamental critique of both of these is that they assume the impossible, a "creation ex nihilo" (ibid., p.I23). In book III, in the chapter that discusses science and causality after an account of something he calls the "mimetic" rite, yet another critique of a rival theory is that it fails to understand what is going on, since it fails to understand "the creation of something entirely new", which is, in fact, "creation properly so-called" (ibid., p.509-510). So a question to ask of Durkheim himself is how, without assuming a creation out of nothing, he can identify a creation of the totally new.

Let us first note various different cases in which effervescence is his same key to things, as in the birth, already mentioned, of "the religious idea". It is unclear what he means by this term. A link can nonetheless be made with one of the work's basic claims, that religion is above all about elevating individuals to "a higher life" (ibid., p.592). Running the two arguments together, effervescence helps to generate religion, in processes that lift up and transform embodied physical beings into spiritual, moral personalities.

Scenes of effervescent assembly are also the birthplace of a world of shared, concrete, material symbols, in an account in which these are integral to the formation of more abstract ideas, and in which they do not just express a preexisting social reality but help to create and constitute it. As Durkheim sums up, social life, in all its aspects and at all moments of its history, is only possible thanks to "a vast symbolism" (ibid., p.33I). Put another way, however, it is the social life of collective effervescent times that, in involving the birth and mobilization of symbols, generates and regenerates social life itself. Or in different if essentially similar terms, society can neither create nor recreate itself without, in the same effervescent action, creating a symbolism. 
Effervescence is thus once again the key when, in the work's conclusion, Durkheim makes the much quoted claim, emblazoned on the front cover of a modern paperback edition: "Une société ne peut ni se créer ni se recréer sans, du meme coup, créer de l'idéal” (ibid., p.603). As he goes on to write a few pages later, a day will come when our societies will once again experience moments of "creative effervescence", complete with a surge of new ideals (ibid., p.6ri). However, the French Revolution constitutes his main modern instance of effervescence, and something fundamental is at stake in his earlier comment that the Revolution, with its launch of a new lay religion, was significant as an actual historical case in which society and its essential ideals became the object of a cult, without any "transfiguration" whatever (ibid., p.306). In the context, this clearly seems to mean it came without any "mystification" whatever, and to express Durkheim's own deep commitment to ideals of enlightenment, a commitment it is important to remember even or especially in all his concern with effervescent emotion, forests of symbols and an imaginative aesthetic "surplus".

However, let us press on to a crucial passage that, in encapsulating an overall theme of the work, brings it towards a final, overall conclusion.

Entre le monde des sens et des appétits d'une part, celui de la raison et de la morale de l'autre, la distance est si considérable que le second semble n'avoir pu se surajouter au premier que par un acte créateur. - Mais attributer à la société ce rôle prépondérant dans la genèse de notre nature, ce n'est pas nier cette création ; car la société dispose précisément d'une puissance créatrice qu'aucun être observable ne peut égaler (ibid., p.637).

One of the points to note about this is not just that Durkheim emphasizes the creativity par excellence of society, whatever the case with a hidden, unobservable god, but that he expresses the very idea of creativity through talk of a "creative power"-as in the reference here to the reality of society's puissance créatrice, or, earlier on, to the imagination of a god's pouvoir créateur (ibid., p.420). Accordingly, something else to note is how his work involves the mobilization of four basic terms, puissance/pouvoir/énergie/force, and that the first two of these elude capture by the solo English equivalent, "power", while the overall discourse also very much includes "energy" and does not just reduce, as in 
some commentaries, to a mechanistic, monochrome vocabulary of "force". A follow-up point is that it would be a formidable task, which does not so far appear to have been undertaken, to go through Les Formes to analyze in detail its usage of this fourfold discourse. However, returning to the passage itself, it continues with an entirely general argument that, far from being a merely mystical operation, "all creation" is the product of a "synthesis".

So it is necessary to ask what Durkheim means by "synthesis", but the key question is what kind of solution it might offer to the issue of creativity itself.

\section{A PROBLEMATIC?}

A route to misinterpreting Durkheim is to try to extract from his work an easy, undemanding, one-dimensional way of thinking. On the contrary, a characteristic concern of his thought is with "antinomies", "contradictions", "oppositions", "dualisms", "dualities". Perhaps the most famous of these involve his interest in the relations of the profane/sacred and the individual/collective. Less familiar concerns are with the immanent/transcendent and the animal/human. In any case, insofar as his overall thought and work constitute a developing, coherent "totality", it is as much as anything the totality of a web of problematics.

The relationship between causality and creativity is part of this web, if only because it involves the antinomy, necessity/freedom, and if only because this becomes apparent when art is discussed in Les Formes in terms of "free creations of the mind", "free combinations of thought and action", and the energies of a "surplus".

But although it might well be linked with this question of freedom and some sort of break in a causal chain, another aspect of things centres round the issue of how, without the mysteriousness of a creation from nothing, there can be a creation of something radically new. Indeed, it is especially here that Durkheim can run into accusations of incoherence, circularity and the petitio principii of accounts that already assume what they set out to understand and explain. Thus a long-running debate among commentators on Les Formes is about its view of the relationship of beliefs with rites and practices, and which of these is in the end 
seen as fundamental and anchored in the other. However, the debate distracts attention not just from Durkheim's insistent effort to anchor both of them in society, but from an argument about society as a creative power in which, right from the beginning of human life, it is the social that helps to create the social. Even though there is a focus, at this or that particular point in an unfolding story, on the role of assembly, or of symbolism and art, or of beliefs in the form of ideals, it remains the case that the basic overall concern is not only with the social but, also and not least, with society's power to create and recreate itself.

It is superficial merely to complain about the argument's logical incoherence and circularity. This fails to address its roots in Durkheim's whole worldview and appeal to an irreducible, sui generis realm of the social. Indeed, a reason for approaching his thought as a web of problematics is to be found in his insistence on "breaks in continuity" and general opposition to a reductionist, one-dimensional commensurability of everything. In any case, to get to grips with his interest in creativity, it is essential to explore his concern with the dynamics of a sui generis realm of human social life.

\section{A SUI GENERIS REALM OF THE SOCIAL}

Throughout his sociological career, Durkheim was highly critical of attempts to reduce human social life to a matter of individual psychology or biology, and was adamant that it constituted, instead, a distinctive sui generis realm of its own. But although there are important continuities in the way he approached and argued for this claim, the development of his thought also involved significant differences. Thus he probably took around ten years to complete his main doctoral thesis, De la Division du travail social, eventually submitted in March I892, printed in time for circulation to members of the examining jury that met early the following year, and then published commercially as a book later in I893. The thesis already mobilizes, like his last great work, a discourse of puissance/pouvoir/énergie/force. Indeed, a relatively early passage also mobilizes an argument about energies that, coming together in assembly, help to generate new, highly powerful, collective forces and emotions - although it refers, not to an effervescence of these energies but to a surexcitation, and not to 
their synthesis but to their fusion (Durkheim, I893a/i893b, p.105-106). Yet the argument is never then taken up in the rest of the thesis and developed in a sustained way to occupy a major, overall role. In particular, it is never taken up and developed into a positive message about the very idea of a creative power. On the contrary, the rare references to creation are virtually all negative in tone, as in the dismissal of theories that rely on "libres créations de l'initiative privée", “créations artificielles” or a "création ex nihilo” (ibid., p.30, 157, 216, 288, 309).

But perhaps the main difference in approach concerns the issue of social evolution. Throughout his career, Durkheim pictured an early segmental society based on clans. In his thesis, however, this comes across as an overwhelmingly collectivist and static world. There is nonetheless, at some point, a "break in equilibrium" that sets off processes of unceasing change in which the division of labour is the "motor of progress" and "everything happens mechanically" (ibid., p.299). As a discussion of various cases had already emphasized, phenomena such as individualism do not date from this or that moment such as the French Revolution, but gradually arise and develop throughout history "without any break in continuity" (ibid., p.I86).

An interest in the dynamics of long-term change remains a basic, integral part of the landscape of Les Formes. Yet as, for example, in book II, chapter IX, and its account of interlinked long-term changes in social organization and religious ideas, these dynamics are already very much at work in Durkheim's early elementary society itself - now identified as a world based not only on clans but also on totemism, and approached through the paradigmatic case, not of an ancient, historically documented Israel, but of the modern ethnography of Australia. In once again looking for the main difference, however, it can be found in all the concern with special effervescent moments, even or especially as a key part of long-term dynamics.

This concern is bound up with the emergence, not just of a duality of two domains of the sacred and profane (Durkheim, I898a, I899), but with his eventual realization of the central theoretical importance of a duality of two times of the sacred and profane (Durkheim, 1907). In turn, what also emerged in writing up a manuscript of Les Formes was how this involved a double duality. 
While one is an affair of alternating sacred and profane times in the rhythms of an established social calendar, the other is about rupture, in which the French Revolution is his star case of effervescence as a special, historically momentous and transformative time (see Durkheim, i9iı).

It is accordingly necessary, in exploring his insistence on an irreducible realm of the social, to look beyond the continuities of a calendar's rhythms as well as of gradual change, and to bring in revolutions. However, an essential preliminary task is to ask about synthesis along with duality.

\section{I.SYNTHESIS/FUSION}

As already noted, the conclusion to Les Formes comes with arguments not just about society as a creative power but about the basis of all creation in the scientifically intelligible, non-mystical operation of "synthesis" (Durkheim, 1912, p.637). In De la Division du travail, however, the same term is put to a negative use in a critique of grand philosophical "syntheses" of knowledge that, with increasing scientific specialization, are merely vague, premature generalizations (Durkheim, I893a/ı893b, p.405, 408). Instead, and again as already noted, the thesis describes a case involving the effervescent creation of a new collective idea as a process of "fusion" (ibid., p.ro6).

Even so, it uses this term in different ways, and in fact the main way is how, in the evolution towards a division of labour's organically interlocking groups, there is an increasing "fusion" of traditional segments (ibid., p.244, $285,333,414)$. Another way is concerned with the traditional, small-scale, homogeneous world of segmental society itself and how, since the differences between individuals are limited, their "fusion" in a common or collective consciousness can be more complete (ibid., p.i II, 3I8).

A key development and articulation of Durkheim's views came with his essay on individual and collective representations. His examination of the relation between these involved a specific focus on the issue of a sui generis social realm, above all in the essay's final section (Durkheim, I898b, p.293-302). Here, "synthesis" and "fusion" are equivalent terms in an argument about interlinkage and distinctiveness in which, just as physical embodiment forms 
a substratum of individual psychic life, so it is that a mass of associated individuals constitutes the substratum of society. In one case, individual representations have roots in a "synthesis" of physiological elements that are transformed by the very fact of their "fusion"; in the other, collective representations have roots in a "synthesis" and "fusion" of individualistic elements that are transformed in the very process itself (ibid., p.295-296).

Thus Durkheim is committed to an interlinkage of things in which, even or especially in arguing for sui generis orders of reality, he insists they can have only a relative autonomy (ibid., p.293). So a built-in ambiguity is how, at the same time as denying any "break of continuity" between these interlinked orders, he asserts that a higher realm is characterized by "suppleness, flexibility and contingence" compared with a substratum and indeed can become "free", up to a point, from its roots in this (ibid., p.298-299). I would suggest, then, that a way of grasping the ambiguity is through the notion of a creative power that entails, if not a break in continuity, at least a break in deterministic chains of causation.

Durkheim himself goes on to discuss how striking examples of what is at stake in his argument can be found in "the evolution of religion". Collective representations can cut loose from close initial links with a substratum, to combine with one another in all kinds of new "syntheses" and take on "a life of their own" that is more or less autonomous rather than just a product of "social structure"; although it is no doubt impossible to understand the formation of the Greek or Roman pantheon independently of the formation of the city, the gradual merging of an ancient segmental society's clans and so on, things such as the "luxuriant growth of myths and legends" are constructions of religious thought itself rather than simply phenomena "determined by social morphology" (ibid., p.299).

So this helps to support the suggestion about an idea of creativity that breaks up causal chains. However, various other points might now be made, starting with how the essay's interest in the evolution of religion is part of a more general evolutionary perspective. This surfaces explicitly in a remark about different "stages" of reality (ibid., p.298). But what could seem implicit in the whole imagery of "substrata" is a concern with different archaeological layers that have gradually built up and become superimposed on one another. Accordingly, a question that 
can arise is whether or not the logic of the essay's argument for a sui generis social realm depends on some kind of reductionist human history, in which a substratum of social life came first, eventually giving birth to social life itself.

At least the essay is clear that this substratum is in no way an affair of isolated atoms. It is emphasized, on the contrary, that it consists of a set or totality_an ensemble — of associated individuals (ibid., p.293). There is nonetheless an ambiguity in how it is further characterized. On the one hand, it is first described in terms of a system or structure of relations that Durkheim regarded as a matter of social morphology; on the other, it is then also described in terms of the actions and reactions between the particular individual minds - consciences élémentaires - that make up society (ibid., p.293-294). The first characterization is very much rooted in the sociological landscape of Durkheim's thesis, complete with its interest, surfacing in the essay's example of religion, in a gradual evolutionary merging or fusion of the segments typical of early social structures. The second characterization could also still be rooted in an evolutionary perspective. But it might especially seem to evoke the case in which his thesis focuses on the action and reaction of individual consciousnesses in assembly and their effervescent fusion. A difficulty with this interpretation, however, is that his essay comes without anything at all on effervescence, either as word or idea. So this is a point at which to return to ask about Les Formes.

An announcement early on in the work is that religious life, wherever it is observed, always has a definite group as its "substratum" (Durkheim, I9 2, p.6I). Things get more complicated in the five hundred or so pages that follow, and a problematic finally tackled in the conclusion is whether this substratum of religious life is to be found in the actual world, where evil and injustice often reign supreme, or in collective representations and ideals of the good society (ibid., p.60o). In any case, a rather different concern running through the work is with how the body, bodily parts and other physical phenomena constitute the "material substratum" of sacred things such as the soul and sacred forces such as mana (see, e.g., ibid., p.95, 328, 339, 348). Moreover, it is the body that at the same time constitutes a material substratum of the individual (see, e.g., ibid., p.23, 52I). Yet what about social life itself? After all, another early announcement is that 
"society is a sui generis reality" (ibid., p.22). What, then, is its substratum, and how is this transcended through processes of synthesis-cum-fusion?

The point about a sui generis social realm is immediately linked with collective representations and how they are irreducible to the individual since they are a product of many different minds in an immense collaboration "not only in space but also across time" and involving the accumulated experience of "long generations" (ibid., p.22-23). So it is worth repeating that evolutionary concerns remain integral to Les Formes, while nonetheless taking on board all the new emphasis placed on effervescence, as with the issue of religion's substratum and whether it is constituted by the actual or an ideal social world. The solution, it turns out, involves the creation not only of the sacred but also of the ideal through the same social dynamic, an intensification of collective life in times of assembly, generating "a state of effervescence that alters the conditions of psychic activity" (ibid., p.602-603). This concern with assembly and effervescence might be why a passage that soon follows still insists that "social life depends on its substratum", but now seems to downplay an older view in which a substratum of associated individuals is about morphology rather than an interaction of minds, and instead highlights how collective consciousness is the product of "a sui generis synthesis of individual consciousnesses" (ibid., p.605). Or, in a variant of this formula, "society is a synthesis of human consciousnesses" (ibid., p.615). Even so, another new development is how the work's interest in effervescence is in fact linked with a reinvigoration of the issue of social and religious life's "material substratum".

In the central chapter of Les Formes, the detailed ethnography of effervescence in Australia is followed by various interlinked theoretical discussions, not least an account of symbolism. In turn, the chapter's final section builds on this account with a series of key generalizations. A collective sentiment can only become conscious of itself "by fixing on a material object", a process in which the sentiment "participates in the nature of this object, as well as the other way round", so that it is through social needs that apparently distinct notions are "fused together", and "social life makes this fusion possible through the great mental effervescence it brings about” (ibid., p.339). Durkheim had already 
maintained, in leading up to the account of symbolism, that ideas require anchorage in "material things", but had immediately remarked that "the role of matter is reduced, here, to a minimum" (ibid., p.326). He had also gone on to argue that sacredness, not being inherent in the nature of a bewildering multitude of different things invested with it, is merely "added" to these and "superimposed" on the material, empirical world (ibid., p.328). Moreover, it is a formula he often went on to repeat. For example, "the world of representations in which social life unfolds is added to its material substratum, far from arising from it" (ibid., p.389). This can seem difficult to reconcile with an effervescent "fusion" of collective ideas and material symbols, or their mutual "participation" in one another. But a deeper problem is its failure to recognize how, in Durkheim's own actual account of effervescence and its creation of extraordinary collective energies through assembly, symbolism and art, an ineliminable role is played by the embodied individual.

It remains the case that, even if in changes of line over a material substratum, its transcendence by social and religious life is seen as entailing greater freedom. In regard to individuals, collective forces bring them a relative autonomy as persons, in loosening the hold of the senses and developing a power "to think and act through concepts" (ibid., p.389). In regard to collective forces themselves, the energies of effervescence and its synthesis of associated individuals create "a whole world of feelings, ideas and images" that does not just have its own laws but that has "such great independence" that it sometimes plays around in ways that have little or no serious aim except the pleasure of affirming itself in them (ibid., p.605). This can recall the remark, in the essay on individual and collective representations, about religious life's luxurious growth — végétation luxuriante — of myths and legends, and indeed a note refers readers to this earlier essay. But the note also refers, perhaps even more significantly, to an earlier section in Les Formes itself. On looking it up, this is the work's discussion of art, of its role in social and religious life, and of its energies of an effervescent "surplus", complete with "free creations of the mind" and "free combinations of thought and action". 
Let us now turn to Durkheim's concern with duality, a concern running through the whole of Les Formes and its view of an irreducible domain of human social life. It was then taken up again in a paper on religion and the duality of human nature (Durkheim, 1913), but also and more famously in an article the dualism of human nature, where it is once more an integral part of an account that interlinks a sui generis social realm, effervescence and the "singularly fertile and creative psychic process called fusion, the communion of a plurality of individual consciousnesses in a common consciousness" (Durkheim, 1914, p.217).

\subsection{DUALITY}

"Duality" is the term used throughout Les Formes, and I have been unable to locate in it even a single occurrence of "dualism". The situation is slightly different with the discussion paper of I9I3, where "duality" is again the term used throughout, except that there is now a reference to an "ancient dualism", followed by a critique of metaphysical theories that fail to explain how two antagonistic worlds "unite and interpenetrate", and that accordingly leave the impression of an antagonism between two entities existing entirely independently and outside one another, which "renders their marriage unintelligible" (Durkheim, 1913, p.72).

This suggests that the idea defended in Les Formes as well as in the discussion paper involves a sociological concern with a relational duality, as against the metaphysics of an essentialist dualism. So it is perhaps ironic that Durkheim has been so often accused of precisely such an essentialist, metaphysical dualism, not least by sociologists and anthropologists who seem unaware of his talk of duality, and overreliant on a single brief text, his article on a dualism. Indeed, setting aside the article's title and reading through the actual text, again it mainly talks of duality rather than dualism, and again it attacks metaphysical theories that, in setting up two entirely separate worlds, "make their marriage impossible" and are incapable of understanding how they "unite and interpenetrate in a way that gives birth to the hybrid and contradictory beings that we are" (Durkheim, 19I4, p.215). 
In my view, the best, most informed and also most incisive analysis as well as wider contextual discussion of the 19I4 essay has been provided by Giovanni Paoletti (2009; 20I2). In negotiating the complexities of the essay's concern with doubleness as a belief, as a fact and as an outcome to explain, he makes a number of terminological proposals. One is just to accept "dualism" as an obvious way of referring to belief in at least some kind of doubleness, whatever it might be. Another, for want of a better alternative, is also to use "dualism" to describe a substantivist doubleness of two self-standing, heterogeneous orders of reality that might exist in combination, but essentially exist independently, outside or before any such combination. It is then possible to reserve "duality" for a relational doubleness, involving a primal, irreducible correlation of two terms that can only be defined through reference to each other, and that describe essential elements of a relationship that cannot exist independently of this relationship, but are integrally and internally bound up with it (see Paoletti, 2012, p.63-66). So while observing the presence of all these various approaches, the conclusion of his textual analysis of the I9I4 essay is that its "prevailing idea of doubleness is what we have called "relational" doubleness" (ibid., p.68).

What I now wish to show is how, just as relational doubleness is explicitly the idea put forward in the 19I3 paper on duality, it is also the idea at work in Les Formes itself. Thus the introduction to the work provides an early intimation of its interest in a "duality" of the individual-collective (Durkheim, 1912, p.22-27), but without giving away if it is a relational doubleness. However, it might well seem it is nothing of the kind, judging from the work's opening chapter on the definition of religious phenomena. This offers an account in which the separation of the sacred and profane is not just relative but "absolute", involves a thoroughgoing "antagonism" along with a difference in their very "essence", and sets up a need to explain why there has been a more or less universal belief in such "heterogeneous and incomparable worlds", although there is apparently no basis in empirical experience for "so radical a duality" (ibid., p.53-58). The only hint of an alternative picture is a remark that the sacred would be "good for nothing" unless it influenced and interacted with the profane (ibid., p.55). But as the work gets going in earnest, this alternative becomes increasingly evident. 
An early indication of such a development is the attack on theories unable to explain a duality of two beings within us that does not exclude but implies their "profound unity and intimate interpenetration" (ibid., p.79)—while also continuing to attack theories unable to explain how humanity could have arrived at the idea of a duality of "two categories of radically heterogeneous and incomparable things” (ibid., p.r2o). Moving on to the work's central chapter, this includes key accounts of effervescence, symbolism and so on, but also includes a wholly general point about religious forces and how they combine a moral and material character: "the duality of man and nature does not preclude their unity", and "physical and moral forces, while distinct, are closely related" (ibid., p.319, n.I). Moreover, this helps to prepare the way for the argument, already noted, in which ideas require anchorage in concrete, material symbols, and the fusion of these two elements with one another comes about through collective effervescence (ibid., p.339). In the following chapter, it turns out that the duality of body and soul is "in no way absolute", and that there is not only a "close solidarity" between them, but even a "partial overlapping" (ibid., p.347). However, what also turns out is that an altogether crucial duality is within the soul itself, and it often goes unnoticed how Durkheim's account draws on a traditional religious duality of immanence-transcendence. Society, like the "totemic principle", mana and god, is both a vast transcendent power going beyond the individual and an inner immanent energy grounded within human lives, while the soul is a different expression of the same duality, constituting everyone's own particular spark of the divine. In Durkheim's Australia, then, the totemic principle is "immanent in each of the members of the clan", yet, "in penetrating inside individuals, it is inevitable that it is itself individualized" (ibid., p.356). But also and more universally, the "impersonal forces that arise from the collectivity" can only become established through their incorporation within individual consciousnesses, "where they are themselves individualized", and this is not in two different processes, but "in two different aspects of the same process" (ibid., p.382). 
In sum, in the developing arguments in Books I and II, one of the main things to emerge is a relational duality in which the very influence and indeed existence of collective forces depends on their internalization-cum-individualization - a message repeated in the work's overall conclusion (ibid., p.605). The developing arguments in Book III involve a similar, though also in a way an opposite movement. Like the work's opening chapter on the definition of religious phenomena, things kick off in a somewhat dramatic - even melodramatic-fashion. Apparently, there is not just a relative but an absolute "break in continuity" that divides the sacred from the profane, and an essential job of ritual is to keep these domains separate through taboos and prohibitions (ibid., p.428). However, it soon turns out that it is also a job of ritual to overcome such separation, to prepare profane things and beings for participation in the sacred, and, above all, to join individuals together in communion with one another and with the divine, as described in the book's three central chapters on the great "positive" rites of religion. A final chapter then concludes by summarizing a message of the book itself, which is that the job of religion, in all its forms, is the individual's emancipation from egoistic impulses and uplift to "a higher life" (ibid., p.592).

So while a move towards a relational duality takes place in both parts of the work, it goes in opposite although complementary ways, in that one is especially about the integral dependence of collective forces on their individualization to have any impact and power at all, the other about the individual's integral dependence on society for participation in an intellectual and moral, recognizably human life. Together, these arguments have far-reaching implications for Durkheim's entire argument about a distinctive, sui generis social realm and the dynamics of effervescent fusion. If these dynamics help to create society, it is in helping to create the individual as a recognizably human personality. However, there is another corollary. Thanks to a collective effervescence of associated individuals, but also thanks to a relational duality in which these already lead distinctively human lives, the social is already more or less fully implicated from the start in the creation and recreation of the social itself. 
A boring, theoretically unadventurous and superficial option is just to dismiss this as a case of Durkheim's irremediable circularity. An alternative is to imagine an equivalent of a cosmological "big bang", in which a whole relational dynamic somehow got going in a creation ex nihilo that kicked off human history. Or it is possible, instead of abandoning Durkheim's opposition to any mysterious creation out of nothing, to give up on his rigid distinction between human and other animals, and to root his dynamic of social life in processes already taking place among humanity's ancestors. I have explored the first of these alternatives elsewhere (Watts Miller, 20I2, p.I28-I29), and do not have time, here, to explore the second. But I think it is important, in trying to grasp Durkheim's ideas and to take these seriously, not just to cut out the interest in early evolutionary origins that he shared with his contemporaries and pursued throughout his career. It nonetheless remains necessary, even in attempts to avoid the issue of origins, to ask about revolutions rather than only rhythms in order to understand his dynamic of the creation and recreation of social life.

\section{CONCLUSION Rhythms and Revolutions}

What might be seen as an ambiguity is built into the whole project of Les Formes, since its interest in the basic, early and elementary is at the same time a way of trying to uncover the basic, continuing and elemental. A trap is just to read off from Durkheim's Australia that it is also his picture of basic universals, and although his work comes with clear warnings against doing this, he might still seem vague on a range of issues about what is specific to Australia and what is universal. However, his cases of the universal certainly include a need in every society to assemble but also to disperse, since "it cannot remain in session forever", and a response to this need is a "regular alternation of sacred and profane times" (Durkheim, I912, p.499). So this way of formulating things leaves room for his interest both in momentous, revolutionary times and in the rhythms of established social calendar. 
What should also be noted is how the passage concludes by emphasizing Australia as an extreme case, in which the rhythms of social life involve a contrast between alternating ordinary and special times that, as societies develop, becomes increasingly difficult to accommodate (ibid., p.500). Indeed, perhaps things have gone so far nowadays that an alternation between different times is increasingly replaced by a calendar in which they run in parallel, and alongside an uninterrupted, non-stop slot for the routine business of economic and domestic life there is also an uninterrupted, non-stop slot for special gatherings, games, ceremonies, rites and festivals of all kinds. True enough, a necessary implication might be different particular individual timetables within the same collective calendar. But this very point helps to bring out cause for concern about an anomic individualization of time within the shell of a collective calendar.

Coming back to the text of I9I2 itself, it has already been argued that it still involves an interest in gradual processes of long-term evolutionary change, but it can now be added that these might well operate in ordinary rather than only in special ritual times, or, more bluntly, that they necessarily operate throughout and across the rhythms of routine and ritual times. An example involves Durkheim's argument about an underlying evolutionary logic at work in Australia, in which gradually developing structural changes together with their crystallization in initiation rites helped to generate the idea of a high god, endowed with a creative power and a prestige "well above that of other heroes of mythology" (ibid., p.420). This then links with an account in which he sees a high god recognized by different clans as a "synthesis" of all totems of these clans, and a personification of the tribe as a whole (ibid., p.42I). In turn, the underlying logic at stake in this is how, far from being a recent foreign import, the idea of an overall god shared by different Australian peoples arises from an internal "internationalist" dynamic going on among these peoples themselves (ibid., p.422).

Accordingly, his argument seems to me to have at least two corollaries. One is the need to abandon any impression he gives that everyday life in Australia is so routine and monotonous that little or nothing of significance takes place in it. The other is the need to revise his apparent generalization that the essential job of a calendar's special ritual times is just to reinforce and maintain an exis- 
ting collective consciousness. This said, let us move on to the key role played in Les Formes by the effervescence and creativity of historically momentous times and to the French Revolution as Durkheim's star case of these.

It seems to me that, compared with his talk of "synthesis", his talk of "fusion" has much greater explanatory as well as evocative power, through its image of the intense, transformative energies of a cauldron or melting-pot. This helps to get across how, without a creation from nothing, there can still be a creation of the radically new. What is at the same time at stake is how it is a creation entailing a break in a mechanistic causal chain and a degree of indeterminacy and freedom about the outcome of its effervescence. The question, in other words, is how limited or far-ranging this creative freedom might be, a question with roots in Durkheim's belief — as in his thesis, and again in Les Formes - in underlying logics at work in social worlds but also in the overall evolution of humanity itself.

His star case of the French Revolution helps to reveal at least two of these dynamics. Or rather, perhaps, they are two aspects of the same basic dynamic. One is a movement towards an ethic of each different individual's same fundamental moral status and sacredness as a person. The other is a movement away from mystification towards enlightenment and, through science, education but also a whole wider public and shared civic culture, towards the ideal of a transparent society. It is of course possible to argue that, just as profound inequalities are inevitable, so there will always be fogs of mystification of one kind or another. Yet it would itself be a mystification, indeed a travesty, to represent these as Durkheim's own views. This is evident enough from his career as whole. But it is also crystal clear from a posthumously published talk he gave in I9I4 on Les Formes, and what it was all about (Durkheim, 1919).

The conclusion to his talk describes an ongoing crisis, then ends on a note of hope about its eventual resolution. Moreover, worries over a profound if nonetheless passing malaise of modern society had agitated him for some time, especially in his thesis as well as in a new, revised version (Durkheim, 1902) and its subsequent republication (Durkheim, I9I Ib), which appeared just a year before Les Formes and was the edition of La Division du travail cited in it. But it also seems worth noting that worries over a modern crisis concerned him throughout 
his career, from his first sociological publication (Durkheim, I885) to a recently rediscovered article of 1917 on the politics of the future (Durkheim, 1999). Returning to Les Formes, it is significant that, like the conclusion to his talk about it, a passage in its own overall conclusion first describes a crisis in which "we are going through a period of transition and moral mediocrity", then looks forward to an upsurge, as in the Revolution, of a new moment of creative effervescence to help to overcome it (Durkheim, I9I2, p.6Io-6II).

But although the explicit focus in all this is on overcoming the crisis through an effervescent renewal of idealism, what is also at stake is the need for a new organization of society through which to work towards the enactment of this idealism. In Durkheim's long-running worries about modern pathologies and malaise, a recurrent criticism he made of the Revolution was its failure to develop the organization required by its ideals, and the organization he especially had in mind involved a new network of intermediate groups, linking the individual with wider society and indeed helping to constitute society itself. Thus there is a strong case for reformulating his talk of intermediate groups and discussing them, as in the work of Anne Rawls, as constitutive practices. What I would add, however, is that a key need is to grasp the continuing relevance and seriousness of a crisis in which, as he saw it, there has been a sustained, long-term hollowing out of intermediate groups, and a way of doing this is to understand it as a hollowing out of the constitutive practices of society itself.

Perhaps a rebuilding of such groups and practices might develop just through gradual processes of reform within the current socio-political system, and without the extraordinary energies of the new moment of creative effervescence envisaged by Durkheim. Another possibility is that the crisis will just go on, since this moment will never come. Or it might turn out to be an effervescent reinvigoration of ideals of inequality, whether or not together with revitalized clouds of mystification. Even a relative freedom and indeterminacy comes, after all, with its risks. But it seems especially appropriate, in the centenary of Durkheim's death, to end with a general overall remark that goes beyond theoretical arguments about a sui generis social realm, duality and so on. Underlying all these, Durkheim seems to have held on to an obstinate hope in the creative energies inherent in human social life. 


\section{BIBLIOGRAPHY}

DURKHEIM É., 1885, Review of A. Schäffle, Bau und Leben des sozialen Körpers, Revue philosophique, 19, p.446-453. Reprinted in DURKHEIM, 1975, vol. I, p.355-377.

-, 1893a, De la Division du travail social. Thèse présentée à la faculté des lettres de Paris, Paris, Alcan.

-, 1893b, De la Division du travail social. Étude sur l'organisation des sociétés supérieures, Paris, Alcan.

-, I898a, "La prohibition de l'inceste et ses origines", L’Année sociologique, I, p.I-70. Reprinted in DURKHEIM, 1969, p.37-101.

-, 1898b, "Représentations individuelles et représentations collectives", Revue de métaphysique et de morale, 6, p.273-302. Reprinted in DURKHEIM, 1924, p.I-48.

-, 1899, "De la définition des phénomènes religieux", L'Année sociologique 2, p. I-28. Reprinted in DURKHEIM, 1969, p.140-165.

-, 1902, De la division du travail social (second edition), Paris, Alcan.

-, 1907, "Cours de M. Durkheim à la Sorbonne. La religion : Origines", summarized by P. Fontana, Revue de philosophie, 6-10, p.528-539, II, p.92-1I4, p.620-638.

Reprinted in DURKHEIM, 1975, vol. 2, p.65-122.

-, 191 la, "Jugements de valeur et jugements de réalité", Revue de métaphysique et de morale, 19, p.437-453. Reprinted in DURKHEIM, 1924, p.117-142.

-, 191 lb, De la division du travail social (third edition), Paris, Alcan.

-, 1912, Les Formes élémentaires de la vie religieuse. Le système totémique en Australie, Paris, Alcan.

-, 1913, "Le problème religieux et la dualité de la nature humaine", Bulletin de la Société française de philosophie,13, p.63-75, 80-87, 90-100. Reprinted in DURKHEIM, 1975, vol. 2, p.23-59.

-, 1914, "Le dualisme de la nature humaine et ses conditions sociales", Scientia. Organo internationale di sintesi scientifica / Revue internationale de synthèse scientifique, I5, p.206-22I. Reprinted in DURKHEIM, 1970, p.314-322.

-, 1919, "La conception sociale de la religion", talk of I8 January 1914 at conference of the Union de libres penseurs et de libres croyants pour la culture morale, in F. Abauzit (ed.), Le Sentiment religieux à l'heure actuelle, Paris, Vrin, p.96-I05. Reprinted in DURKHEIM, 1970, p.305-313. 
-, 1924, Sociologie et Philosophie, Paris, Alcan.

-, 1969, Journal sociologique, Paris, PUF.

-, 1970, La Science social et l'Action, Paris, PUF.

-, 1975, Textes, 3 vols., Paris, Éditions de Minuit.

-, 1999, "La politique de demain", Durkheimian Studies / Études Durkheimiennes, 5, p.8-12.

PAOLETTI G., 2009, “Introduzione. Identità personale e legame sociale”, in É. Durkheim, Il dualismo della natura umana e le sue condizioni sociali, Pisa, Edizioni ETS, p.5-29.

-, 2012, "Durkheim's 'Dualism of Human Nature': Personal Identity and Social Links", Durkheimian Studies / Études Durkheimiennes, 18, p.61-80.

RAWLS A., 2004, Epistemology and Practice: Durkheim's The Elementary Forms of Religious Life, Cambridge, Cambridge University Press.

SCHMAUS W., 1994, Durkheim's Philosophy of Science and the Sociology of Knowledge: Creating an Intellectual Niche, Chicago, University of Chicago Press.

-, 2004, Rethinking Durkheim and His Tradition, Cambridge, Cambridge University Press.

SPENCER B. and GILLEN F. J., 1899, The Native Tribes of Central Australia, London, Macmillan.

-, 1904, The Northern Tribes of Central Australia, London, Macmillan.

STEDMAN JONES S., 2006, "Action and the Question of the Categories:

A Critique of Rawls", Durkheimian Studies / Études Durkheimiennes, 12, p.37-67.

WATTS MILLER W., 20I2, A Durkheimian Quest: Solidarity and the Sacred, Oxford and New York, Berghahn. 